\title{
Public Opinion on Canadian Arctic Sovereignty and Security
}

\author{
Mathieu Landriault ${ }^{1}$
}

(Received 24 August 2015; accepted in revised form 27 November 2015)

\begin{abstract}
Previous research on Canadian Arctic sovereignty and security has focused on governmental actions and policy recommendations. While these studies have produced some fine scholarship on those matters, Canadian public opinion on Arctic issues has been mostly assumed or analyzed on an anecdotal basis. This paper aims to correct this shortcoming by drawing the contours of public preferences on Arctic issues and assessing the impact of government activism on those preferences. An examination of 18 opinion polls conducted between 2006 and 2015 that questioned respondents directly or indirectly on circumpolar affairs concluded that Canadians do not prioritize the Arctic among other national priorities, although they rank it high as a foreign policy and defense priority. Additionally, even though increasing military presence in the Arctic seems at first glance to receive an exceptionally high level of support, a more careful examination of the data suggests that a majority of Canadians supports an approach to Arctic sovereignty that is rooted in compromises and negotiations.
\end{abstract}

Key words: Arctic sovereignty; Arctic security; Canadian Arctic; public opinion; public preferences; Canadian foreign policy; circumpolar region; opinion polls; issue saliency; military sovereignty

RÉSUMÉ. Par le passé, les études effectuées en matière de souveraineté et de sécurité dans l'Arctique canadien portaient principalement sur les actions du gouvernement et sur les recommandations de politiques. Bien que ces études aient permis d'obtenir de l'excellente information à ce sujet, l'opinion publique des Canadiens à propos des enjeux de l'Arctique a été soit largement présumée, soit analysée en fonction d'anecdotes. Ce document vise à remédier à ce manque en présentant les grandes lignes des préférences du public au sujet des enjeux propres à l'Arctique et en évaluant les incidences de l'activisme du gouvernement à l'égard de ces préférences. L'examen de 18 sondages d'opinion réalisés entre 2006 et 2015, sondages comprenant des questions directes ou indirectes à l'égard des affaires circumpolaires, a permis de conclure que les Canadiens ne classent pas l'Arctique au rang des autres priorités nationales, et ce, même s'ils considèrent l'Arctique comme un sujet important en matière de politique étrangère et de priorité de défense. En outre, même si, a priori, l'intensification de la présence militaire dans l'Arctique semble recevoir un soutien exceptionnellement grand, l'examen plus approfondi des données suggère que la majorité des Canadiens appuie une approche envers la souveraineté de l'Arctique qui est enracinée dans les compromis et les négociations.

Mots clés : souveraineté dans l'Arctique; sécurité dans l'Arctique; Arctique canadien; opinion publique; préférences du public; politique étrangère du Canada; région circumpolaire; sondages d'opinion; importance de l'enjeu; souveraineté militaire

Traduit pour la revue Arctic par Nicole Giguère.

\section{INTRODUCTION}

Public opinion is difficult to delineate with precision. However, on some issues, we see clear manifestations of public preferences being expressed; Arctic sovereignty is such an issue. In 1969 and 1985, sovereignty crises with the United States questioning the status of the Northwest Passage spurred public outrage, intensive media coverage, and pleas for the Canadian government to do more in the Arctic (Rothwell, 1993). Confronted with a passionate popular reaction, an initially passive government adopted a more vigorous approach and reacted with groundbreaking initiatives (e.g., implementation of the Arctic Waters Pollution Prevention Act in 1970; Government of Canada, 2016) and announcements of ambitious investments (proposed construction of a world-class icebreaker in 1985). Although these crises stressed the importance of public opinion, they represented spasms followed by periods of great apathy and indifference. Periodic amnesia is a fundamental characteristic of how most Canadians relate to their northern territory. However, the Arctic still holds great symbolic and political capital among the Canadian public; though few Canadians have ever been to the Arctic, most think Canada's claims there are important (Nicol and Heininen, 2009).

Thus the Arctic is part and parcel of the definition of the Canadian identity. Unfortunately, public preferences on Canadian Arctic Sovereignty and Security (CASS) have not been studied systematically; we have only anecdotal evidence of public support for such policies. Following Huebert (1999), this article considers sovereignty and security

\footnotetext{
${ }^{1}$ Graduate School of Public and International Affairs, Faculty of Social Sciences, University of Ottawa, Ottawa, Ontario K1N 6N5, Canada; mland031@uottawa.ca

(c) The Arctic Institute of North America
} 
in the Canadian Arctic as interrelated issues and not as separate domains. The conceptual boundaries of these two issues are blurred in the context of global warming. Scholarship on CASS has tended to focus on how effective governmental measures are in strengthening Canada's Arctic sovereignty claims or whether Arctic relations are mostly cooperative or mostly conflictual (Coates et al., 2008; Riddell-Dixon, 2008; Huebert, 2009). Public opinion has been assumed to be constant or uniform. Such a position may be understandable considering the few opinion polls conducted on these questions, but it opens the door for sweeping generalizations about public preferences. Since public opinion often influences governmental measures, especially in a democratic regime like Canada (Soroka and Wlezien, 2004; Herle, 2007), evaluating the effectiveness or origin of policies without understanding public opinion would offer only a partial portrait of the situation. Developing a more complex view of public opinion is crucial to informed discussion of Arctic sovereignty and security and may challenge long-held assumptions about how Canadians relate to these issues.

This paper aims to fill this gap by examining 18 opinion polls conducted on CASS from 2006 to 2015 . This inquiry is exploratory in nature, since very little has been done on this front, and has two main goals. The first is to sketch the contours and persistent patterns of public preferences on CASS. Three areas will be investigated: the saliency of Arctic issues in the public mind, Canadians' perceptions of the Arctic, and the solutions the public supports to reinforce CASS. The second goal is to evaluate the influence of geopolitical developments and governmental rhetoric on public opinion of these matters. The release of the second edition of the Rethinking the Top of the World survey funded by the Munk-Gordon Arctic Security Programme in April 2015 allows for such an analysis (EKOS, 2015). In Canada, 2007-10 was a period of activism on CASS, with prominent intellectual debates, frequent opinion polls, and announcements of government policies and investments. The Harper government's active (and at times aggressive) approach towards the Arctic characterized this time (Nossal, 2013:26-27). International relations were also in a state of flux, with many non-Arctic states wanting a role in constructing regional governance of the circumpolar world. However, this dynamism cooled off when the five coastal states on the Arctic Ocean (Canada, Denmark, Norway, the Russian Federation, and the United States) met in Greenland and agreed on shared expectations, as expressed in the Ilulissat Declaration, which included cooperation with other interested parties within the framework of existing legislation (Arctic Ocean Conference, 2008). The relative stability resulted in a quasi-absence of any opinion polls published on these questions, especially in Canada, where the bulk of Arctic announcements were made before 2010. The publication of the 2015 Rethinking survey allows insights into possible changes in public preferences. Can we observe a change in public opinion of the Arctic since 2010, when the Canadian government became less active in framing
Arctic issues as sovereignty issues? Before assessing the data collected, it is imperative to look at how past researchers studied CASS.

\section{CANADA AS AN ARCTIC COUNTRY}

Canada established its legal and constabulary presence in the Arctic in the first half of the 20th century with the objective of asserting sovereignty over this sparsely populated area (Grant, 2005). The Arctic was also a unifying idea in building Canada as a nation and remains a marker of Canadian identity today; it helped to define Canada as a northern country and to unite francophones and anglophones (Griffiths, 1979; Lasserre, 1998; Arnold, 2010).

The media have been perceived as promoting the notion that the United States had refused to consult Canada over the 1969 transit of the Northwest Passage by SS Manhattan (although bilateral consultations had taken place) and thus strengthening the idea that the American action was a direct threat to Canadian sovereignty (Rothwell, 1993). Public alarm and nationalist sentiments pushed the Government of Canada to enact ambitious measures to address these concerns, which included extending Canadian maritime jurisdiction through the Arctic Waters Pollution Prevention Act in 1970. However, the Canadian Arctic was quickly forgotten once these sovereignty crises faded.

Scholarship tended to follow the same boom-and-bust pattern (Cornut, 2010). Studies on Arctic sovereignty and security were focused on two main axes of interest: the juridico-legal status of the Arctic archipelago and the Northwest Passage on the one hand, and the strategic role of the Arctic vis-à-vis the USSR in the global confrontation of the Cold War. The pioneering work of Donat Pharand (Pharand, 1979; Vanderzwaag and Pharand, 1983) came to characterize the former, while the latter was mostly investigated through a strategic studies lens by realist authors such as Critchley (1984). In the cooperative international environment that emerged at the end of the Cold War, academic attention turned to comparing potential institutional arrangements that would lay the basis for regional governance in the Arctic. The diplomatic efforts that led to creation of the Arctic Council are examples of this phenomenon (Scrivener, 1999; Roussel and Fossum, 2010).

In the past few decades, a debate centered on the impacts of global warming on the Canadian Arctic has emerged. This exchange was initially led by two scholars, Rob Huebert and Franklyn Griffiths, who disagreed on the extent of the challenge that global warming posed to Canada's Arctic sovereignty claims. However, like most Arctic scholars, both agree that the Canadian government abandoned the region and withdrew key investments, which led them to suggest that the Government of Canada should do more to ensure a stronger presence (whether military or civil) in its portion of the Arctic (Huebert, 1999; Griffiths, 2009). This same debate has persisted since, with Whitney Lackenbauer $(2010,2013)$ replacing Griffiths as the main 
proponent of a more moderate position on the consequences of global warming for Canadian sovereignty claims. This moderate opinion was also dominant in the Canadian media views on the region, although the Arctic was not a subject of great interest from 2000 to 2005 (Landriault, 2013:53-96).

The dominant focus in the first decade of the new millennium was speculative assessment of the transformative effect of climate change on the geopolitical reality of the Arctic region. Policy-making recommendation was the principal angle taken by scholars within this sub-field of inquiry. The assessment of different emerging state and non-state threats to Canada's Arctic sovereignty and security constituted the norm, with a heavier focus on state behaviors and interests. Activism by the governments of Denmark (Huebert, 2005; Stevenson, 2007), the United States (Huebert, 2009; Byers, 2010a), and Russia (Byers, 2010b; Lackenbauer, 2010; Charron et al., 2012) was analyzed in detail to evaluate their intentions in regard to the development of the Arctic. More recently, non-Arctic countries have been scrutinized, with China monopolizing attention (Wright, 2011; Manicom and Lackenbauer, 2013; Huang et al., 2015).

Governmental policy has been the focus of most scholarly studies of Canadian Arctic security and sovereignty issues. As a result, Canadian public opinion preferences and perceptions of the Arctic have been little investigated. Of course, popular perceptions and representations of the Canadian Arctic have been studied previously, although not in a statistical fashion, giving attention primarily to northern symbols, myths, and narratives present in Canadian culture and in the construction of Canadian identity. Many studies have chosen to direct their attention to specific (often historical) case studies (Grant, 2005; Arnold, 2008, 2010) of how these perceptions have colored governmental or cultural practices of the North or the Arctic that are considered to be part of Canadian national identity (Lasserre, 1998; Coates and Morrison, 2000; Williams, 2011).

In many cases, public opinion and popular perceptions have been assumed without clear empirical evidence. For example, Griffiths (2009:26) wrote that "prone to exaggerated threat assessment and overly insistent on the need for hardware to assert control, Canadians in the grip of possession anxiety are given to self-doubt when actually the outlook is good...Canadians worry, and journalists and editorialists feed on this worry...they join a misguided discourse and reinforce it by committing to still more resolute defenses of sovereignty." Lackenbauer (2009:2) expresses a similar idea when he states that "tapping into primordial national anxieties about the potential loss of sovereigntyusually to the behemoth to the South - this threat resonates with Southern Canadians who have taken little interest in their Arctic and have been led to believe that military capabilities will shield Canada." Others have also defended the idea that Canadians have great (often misguided) fears about Arctic sovereignty (Riddell-Dixon, 2008; Coates et al., 2009; Nicol and Heininen, 2009). Those authors assume that interest in the Arctic is sporadic for most Canadians, but that from time to time, counterintuitively, the region is elevated to the status of national concern.

Another assumption is that most Canadians perceive military presence as the primary means to push Canada's Arctic claims (Roussel, 2010). A last (implicit) assumption is that public opinion reacts directly to social and political pressures (from the media and government), a claim that is difficult to prove. In attempting to do so, this paper divides the time in two: 2007-10, a period of great media and governmental activism on Arctic matters (Landriault, 2013), and 2011-15, a period with little such activity.

Little attention has been devoted to opinion polls as a way to pinpoint patterns of public preferences and support these claims with systematic evidence. This paper gathers data from 18 opinion polls conducted between 2006 and 2015 that questioned Canadians either directly or indirectly on the Arctic (Table 1). Different commercial polling firms conducted these inquiries: Nanos Research (7 polls), Angus Reid (4), Ipsos Reid (3), EKOS (2) and Environics (2). All surveys were of high quality and used rigorous methods. Samples were representative of the Canadian population, allowing for generalizations to the whole Canadian population, and the surveys were done either by telephone or through an online panel whose members were randomly recruited to participate. Wording and question format varied from poll to poll, and the impact of these variations will be discussed in subsequent sections. The first concern is to understand whether Canadians consider Arctic sovereignty and security to be pressing issues that demand immediate attention and considerable resources.

\section{ISSUE SALIENCY AND PRIORITY}

Are CASS issues considered a priority by the Canadian public? To answer this question, we need to distinguish between polls in which the Arctic was suggested as an answer and those in which it was not. In those surveys that did not prompt respondents, the Arctic does not appear to be on the political radar of Canadians. The Arctic is under the bar of 3\% in three Nanos Research polls that asked people to name their most important national issue of concern (Nanos Research, 2009, 2010a, 2014). Questions about what Canada's top international priority should be produced a similar result (Anon., 2008). When questioned explicitly on the importance of the Arctic region in relation to other priorities, Canadians reemphasize the relatively low level of priority given to this policy area. In Nanos polls conducted in 2011 and 2012, asserting Arctic sovereignty came at the very bottom of the list of national priorities (Fig. 1). A similar conclusion can be reached for a 2008 Ipsos Reid poll that placed asserting Arctic sovereignty last in a list of eight priorities, trailing behind even the highly unpopular mission in Afghanistan (Ipsos Reid, 2008).

Nonetheless, there is a general, albeit vague and abstract, consensus that Canada should do more by investing heavily in its Arctic region. This statement gathered the assent 
TABLE 1. Chronological list of opinion polls used in this study and the main slant of each inquiry.

\begin{tabular}{llll}
\hline \hline Poll \# & Time of poll & Polling firm & Subject matter \\
\hline 1 & August 2006 & Ipsos Reid & Prime Minister's Arctic tour \\
2 & February 2007 & Angus Reid & Preferred approach to Canadian Arctic sovereignty \\
3 & August 2007 & Angus Reid & Reactions to Russian actions \\
4 & November 2007 & Angus Reid & Ownership of Arctic resources \\
5 & August 2008 & Ipsos Reid & Government Arctic investments \\
6 & August 2008 & Angus Reid & Nature of threats in Arctic \\
7 & October 2008 & Nanos Research & National issues of concern in Canada \\
8 & December 2007-January 2008 & Environics & Foreign affairs priority \\
9 & January-February 2009 & Environics & Arctic security and sovereignty \\
10 & March 2009 & Nanos Research & National issues of concern in Canada \\
11 & November 2009 & Ipsos Reid & Knowledge of Inuit and North \\
12 & November 2010 & EKOS & Arctic security and sovereignty \\
13 & May-June 2010 & National issues of concern in Canada \\
14 & October 2010 & Nanos Research & National defense priorities \\
15 & May 2011 & Nanos Research & Long-term priorities in Canada \\
16 & May 2012 & Nanos Research & Long-term priorities in Canada \\
17 & September-October 2014 & Nanos Research & National issues of concern in Canada \\
18 & March 2015 & EKOS & Arctic security and sovereignty \\
\hline \hline
\end{tabular}

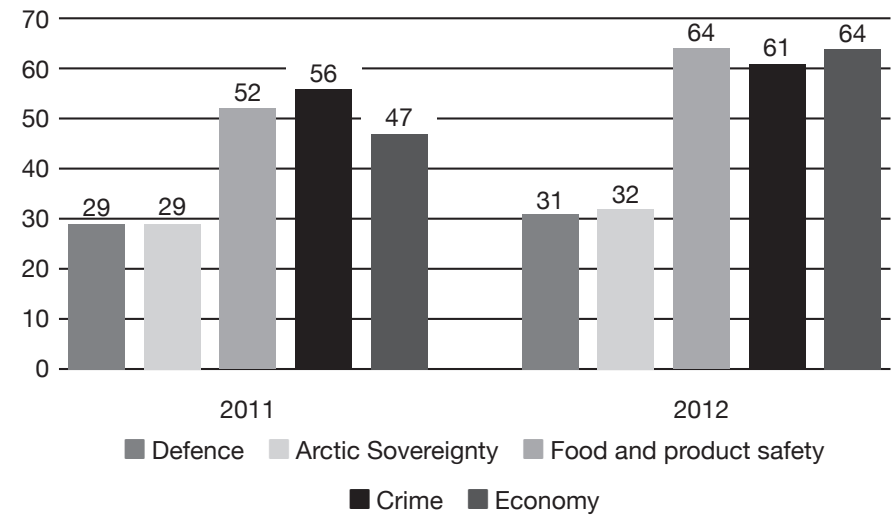

FIG. 1. Long-term priorities of Canadians as expressed in Nanos Research surveys conducted in May 2011 and May 2012. The numbers above each bar indicate the percentage of respondents that gave priority to each issue.

of $75 \%$ to $80 \%$ of respondents in three different polls from 2007 to 2009, even after major new investments were announced by the Government of Canada (Angus Reid, 2007b, 2008; Public Works and Government Services Canada, 2010:18). The quasi absence (12\%) of interviewees advocating that Canada should do less for the Arctic (Ipsos Reid, 2008) also contributes to making the Arctic policy area one with very few opponents; apathy and forgetfulness represent more difficult challenges.

Moreover, CASS registers as an issue specifically rooted in foreign policy and defense matters. Indeed, in the 2010 edition of the Rethinking the Top of the World inquiry, 54\% of respondents agreed that the Arctic should be the number one priority of Canada's foreign policy (EKOS, 2011). The region also arrived at the top of the foreign policy priority list (out of five options) in a 2008 poll (Anon., 2008). In defense policy, increasing military defense in the Arctic ranked third by respondents, behind only peacekeeping and North American security co-operation (Nanos Research, 2010b).

Thus Arctic sovereignty does not appear to be naturally on people's minds even in a period of great activism (from 2007 to 2010, for example). Rather, it is a minor concern or relegated to specific areas of governmental activity. Nothing in these surveys points in the direction of issues deemed salient by the Canadian population. The Arctic was placed last in all seven polls (Ipsos Reid, 2008; Nanos Research, 2008, 2009, 2010b, 2011, 2012; EKOS, 2010) that asked respondents to rank different public policy domains in order of priority. The region found resonance when framed in specific policy areas, like defense or foreign affairs; all three polls (Environics, 2007-08, 2009; EKOS, 2010) linking the Arctic to these subject matters suggested that the region was considered a top priority.

\section{CANADIAN ARCTIC PERCEPTIONS}

Are Canadians taken with a possession anxiety, as argued by Griffiths? Belief in erroneous information about the circumpolar world is widespread and can create a false sense of entitlement to polar territory and resources. According to a November 2007 poll, 53\% of Canadians understood that the natural resources at the bottom of the Arctic Ocean belong to Canada, a claim that needs to be substantiated given that other countries also claim that the Arctic continental shelf is theirs (Angus Reid, 2007a). A similarly confident (and factually wrong) stance can be reported from a 2015 poll on the Northwest Passage, in which only $28 \%$ of Canadians interviewed gave the correct response, describing the status of the Northwest Passage as in dispute (EKOS, 2015:7). Additionally, only 30\% of respondents correctly identified the Arctic Ocean (rather than the Northwest Passage) as Canada's northern boundary. No notable differences can be established on this last point between Northerners and Southerners, since both made the mistake in the same proportion (Public Works and Government Services Canada, 2010:18).

Inquiries that measured the level of national anxiety about a possible loss of Arctic sovereignty offer a mixed (and confusing) portrait of public preferences. In a 2009 Environics survey commissioned by the Department of 


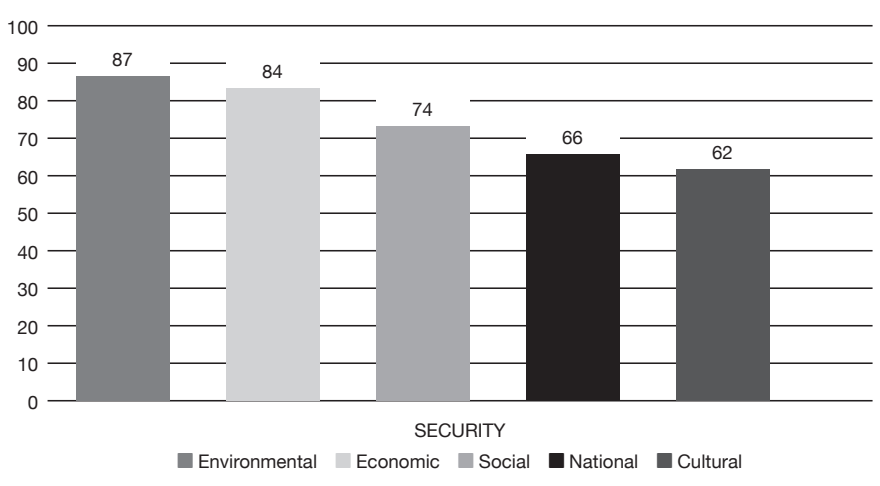

FIG. 2. Relative importance of five definitions of Arctic security as expressed in the EKOS polls (EKOS, 2011, 2015). Percentage of respondents who considered each to be important for protection of the Arctic (EKOS, 2011).

National Defense, $54 \%$ of Canadians questioned believed that the country currently faced a threat to its Arctic sovereignty and to the security of its northern border (Public Works and Government Services Canada, 2010:18). Similarly, in a 2010 poll (Nanos Research, 2010b), only 19\% of respondents did not see major Arctic players as a threat to Canada's Arctic territory; most Canadians perceived these state actors as representing some kind of danger to Canadian sovereignty. The possession anxiety hypothesis seems to find unequivocal support in these two polls.

Again, however, question format matters. In fact, quite a different picture emerged when subjects were asked, unprompted, to name the most important issue facing the Canadian Arctic. The belief that there is a threat to Canada's sovereignty falls sharply to $16 \%$, and the environment is mentioned more than twice as often (EKOS, 2011). Moreover, interviewees tended to think of security more in terms of environmental protection or social and economic needs rather than in terms of national or physical security threats (see Fig. 2). These findings indicate that external threats to Arctic sovereignty take a backseat to internal problems such as lack of socio-economic development and environmental protection.

Since it is difficult to perceive a consensus on the level of danger to which Canada is exposed in the Arctic region, the type of solution preferred by Canadians to assert Canada's claim could possibly help us clarify this aspect. If national anxiety about the loss of sovereignty grows, it is likely that support for additional military capabilities will follow.

\section{HOW TO DEFEND A NORTHERN BORDER?}

Given the long history of engagement of the Canadian Armed Forces in the Arctic (Lackenbauer and Farish, 2007), the military institution seems to be a logical choice to reaffirm Canada's Arctic sovereignty and guarantee Arctic security. However, since most Canadians perceive the Arctic as a foreign policy issue, they give wide support to reliance on international organizations, construction of international laws and norms, and the search for compromise and negotiations, even when faced with a staunch

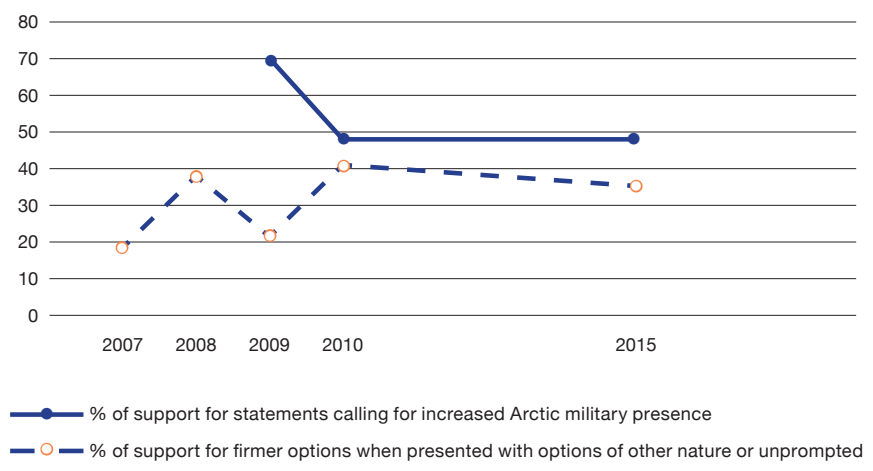

FIG. 3. Levels of support for the conservative approach as shown in 17 polls conducted from 2007 to 2015 .

government rhetoric opposing these strategies (Paris, 2014). This liberal approach based on conciliation and diplomacy contrasts with a conservative one based on firmness and rooted in military strength, resources, and presence. This divide has been tracked in different opinion polls to assess the type of Arctic activism desired by Canadians. A majority of Canadians support a bolstered military presence and increased military resources in the polar region, although this support has declined as relations between the nations bordering the Arctic have improved (see Fig. 3).

Examining only polls that ask respondents whether or not they support an increase of military resources leaves the observer with a partial understanding of public preferences. Indeed, when asked if they agreed with statements calling for an increased Canadian military presence, $50 \%$ to $70 \%$ of respondents supported such statements. At first glance, the militaristic solution seems to garner an exceptionally high level of support from the Canadian populace. However, similar questions on other types of Arctic priorities earned even higher degrees of approbation. For example, higher levels of agreement were expressed for strengthening climate change policies and Inuit culture and language (EKOS, 2011). In fact, strengthening military presence was last on a list of various priorities (culture, socio-economic needs, environmental regulation), which casts quite a different light on the popularity of the conservative approach.

The 2010 Rethinking the Top of the World survey introduced doubt about the supposedly widespread agreement regarding Arctic military spending. Indeed, when respondents were asked to pick one of two public policy options, they chose increasing Canadian military presence in only $31 \%$ of cases, compared to $57 \%$ for providing more regulations to protect the environment and $68 \%$ for building better infrastructure (EKOS, 2011). Accordingly, when asked what Canada needs to do to defend its Arctic claims, Canadians seem to choose "greater military presence" as the default answer; however, this choice may express a natural association of military with the Arctic based on history, rather than their true preferences. In a 2009 Environics poll (Public Works and Government Services Canada, 2010), when asked to propose possible solutions to secure Canada's claim, respondents gave the military solution 


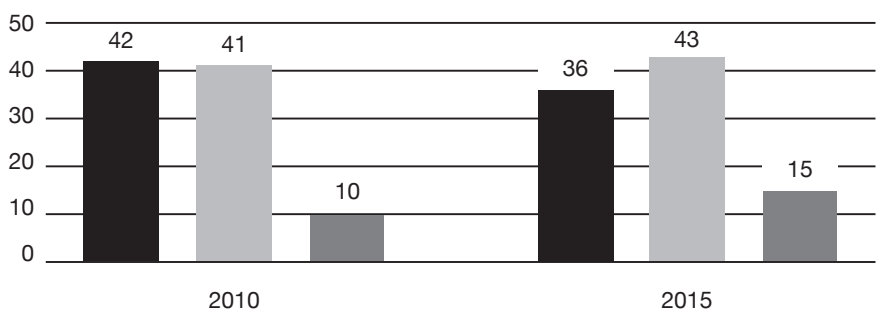

My country should pursue a firm line

My country should negotiate a compromise with other countries

The Arctic should be an international territory like Antarctica

FIG. 4. Preferred approaches to solving international disputes over Arctic borders and resources, as expressed in the Rethinking the Top of the World surveys conducted in 2010 and 2015 (EKOS, 2011, 2015).

first place. However, when given four options (including a greater military presence), they strongly preferred negotiations with other countries and mapping of Arctic geography and resources (Public Works and Government Services Canada, 2010:18). This result highlights the importance of presenting the full breadth of possible policies to the Canadian public to get a clearer picture of public preferences. Both the Environics poll in 2009 and the EKOS poll in 2010 asked respondents to rank the military option and other options by preference, and both results highlighted the low level of popular support for a militaristic strategy.

Another pattern that can be discerned from scrutinizing opinion polls is the general thirst for a rule-based region. This desire is especially clear from the 2010 and 2015 Rethinking polls. Overwhelming support for the creation of a nuclear-free zone in the Arctic (77\% in $2010,80 \%$ in $2015)$, coupled with majority support (61\% in $2010,55 \%$ in $2015)$ to extend the Arctic Council mandate to cover military security, are telling in this regard (EKOS, 2011, 2015). Likewise, the preferred approaches to border disputes are fostering common understanding and respecting common norms and rules (Fig. 4).

It should be noted that the "international territory" option is seen as an extension of the "negotiating a compromise" option, rather than as a contradiction to it. The international territory option would make the Arctic an area open to all and limit activities that could potentially take place in the region. The Arctic region would be faced with a treatment similar to that of Antarctica under the Antarctica treaty. Hence, both options can be understood as part of a liberal approach to international relations, which emphasizes conciliation and diplomacy. Taken together, they garnered the support of $51 \%$ of respondents in 2010 and $58 \%$ in 2015.

The rise of the international territory option could have been prompted by activism by vocal non-governmental organizations, such as Greenpeace, that propose creating an Arctic sanctuary free of commercial fishing, drilling, and mining. However, looking at opinion polls, we can find evidence that this idea already had a solid base in Canada's public consciousness. In a 2008 poll, a majority of Canadians (57\%) supported the position that Canada should leave the Arctic ecosystem relatively untouched by natural resource extraction (Ipsos Reid, 2008). Two years later, in an EKOS poll (2011:31) that asked respondents to rank 12 priorities for the Canadian Arctic region, the option of "increasing the development of mining of natural resources" ranked tenth in priority. The Canadian public did not accept the idea that it was urgent to extract natural resources as an exercise of sovereignty - and to do so sooner, rather than later, to fend off potential foreign rivals.

Government activism and media coverage seem to have affected public preferences. Different outcomes could have resulted during the time of more turbulent Arctic relations from 2007 to 2010. For example, Canadians could have perceived diplomacy and the search for compromise as a preferable way to counteract instability and uncertainty about Canada's Arctic claims or to oppose the Harper government's aggressive, pro-military approach to these matters. This scenario did not materialize. Instead, we have seen public opinion being influenced by governmental rhetoric and media coverage that questioned the solidity of Canada's claims. These pressures broadened public support for a firmer approach to solving disputes that emphasized increasing the presence of the Canadian Armed Forces north of 60. Support for more military muscle decreased after 2010 as the dust settled on most contentious Arctic issues.

\section{CONCLUSION}

CASS issues remain puzzling. Compared to other national priorities, they arouse only peripheral interest, yet the public would place them at the top of the foreign policy agenda. Despite feeling that government should invest more heavily in the Arctic, Canadians made no uproar when the Conservative government downgraded initial investments (fueling station, offshore patrol ships) and postponed others (icebreaker). In this regard, the present data support the conclusion of Coates et al. (2008:147) that there are "few, if any, consequences from backing away from commitments to protecting the North from future intrusions."

As for the perception of threats, evidence is mixed, and any conclusion is rendered more complex by the misconceptions about this region (especially factual information about geography, people, and international law) that many Canadians share. Certainly, we cannot pretend that Canadians are possessed by uncontrollable anxiety attacks about a possible loss of Arctic sovereignty; this fear did not materialize in the opinion polls analyzed. Hence, the idea that the Canadian population shares fearful assessments about Canadian Arctic sovereignty because certain media, academic, and political elites are popularizing these narratives does not gather empirical traction.

Additionally, Canadians are not as supportive of bolstering Canada's military presence in the Arctic as first thought, especially when the military option is presented 
alongside socio-economic, environmental, or cultural alternatives. In these cases, a military-centered strategy does not seem to be the preferred solution of Canadians to assert Arctic sovereignty. Rather, what emerges is a much more complex picture of public preferences for possible future solutions. Support for an approach rooted in conciliation and regional regime building is much more robust than support for confrontation and exclusion. Hence, if we think that governments in democratic regimes must respond at least partially to public preferences, the Canadian government should note the suggestion of the public to move away from a military-first approach. The logical rationale presented by Lackenbauer - that specific elites created national, popular anxiety, prompting calls for more defense spending - then breaks down, since the national anxiety element is certainly not predominant in Canadian public opinion.

Canadian public opinion regarding Russia is indicative of this phenomenon. Even though most Canadians viewed Russia's involvement in the Ukrainian conflict as a serious threat (Angus Reid, 2014), a majority of Canadians (63\%) did not think that Arctic cooperation with Russia should be suspended (EKOS, 2015:3), favoring engagement rather than isolation. It is worthwhile mentioning that this bias towards a conciliatory approach increased with the downplay of power politics rhetoric in the Arctic and media coverage raising the specter of threats to Arctic sovereignty. Thus, public preferences can be tilted in specific directions, which makes them particularly susceptible to partisan political messaging.

\section{ACKNOWLEDGEMENTS}

The author would like to thank Rachel Côté and the three anonymous reviewers for their helpful comments.

\section{REFERENCES}

Angus Reid. 2007a. Americans side with Canada on Northwest Passage. Angus Reid Global Monitor, November 29.

. 2007b. Canadians split on Harper's commitment to Arctic. Angus Reid Global Monitor, August 21.

- 2008. Canadians adamant on Arctic sovereignty. Angus Reid Global Monitor, August 22.

- 2014. Ukraine crisis: Poll shows American, British \& Canadian appetite for economic sanctions high. Angus Reid Global, May 6.

http://angusreidglobal.com/wp-content/uploads/ 2014/07/2014.05.02-ARG-Ukraine-survey.pdf

Anon. 2008. Arctic should be our top international priority. Edmonton Journal, July 12.

Arctic Ocean Conference. 2008. The Ilulissat Declaration. 27-29

May 2008, Ilulissat, Greenland.

http://www.oceanlaw.org/downloads/arctic/Ilulissat_ Declaration.pdf
Arnold, S. 2008. Nelvana of the North, traditional knowledge, and the northern dimension of Canadian foreign policy. Canadian Foreign Policy Journal 14(2):95-107. http://dx.doi.org/10.1080/11926422.2008.9673465

— 2010. "The Men of the North" redux: Nanook and the Canadian national unity. American Review of Canadian Studies 40(4):452-463.

Byers, M. 2010a. It's time to resolve our Arctic differences. The Globe and Mail, April 30.

- 2010b. Russian bombers a make-believe threat. Toronto Star, August 30.

Charron, A., Plouffe, J., and Roussel, S. 2012. The Russian Arctic hegemon: Foreign policy implications for Canada. Canadian Foreign Policy Journal 18(1):38-50. http://dx.doi.org/10.1080/11926422.2012.674384

Coates, K., and Morrison, W. 2000. Winter and the shaping of northern history: Reflections from the Canadian North. In: Sigurðsson and Skaptason, J., eds. Aspects of Arctic and subArctic history: Proceeding of the International Congress on the History of the Arctic and Sub-Arctic Region, 18-21 June 1998, Reykjavik, Iceland. Reykjavik: University of Iceland Press. 409-419.

Coates, K.S., Lackenbauer, P.W., Morrison, W.R., and Poelzer, G. 2008. Arctic front: Defending Canada in the far North. Toronto: Thomas Allen Publishers.

Cornut, J. 2010. Why and when we study the Arctic in Canada. International Journal 65(4):943-953. http://dx.doi.org/10.1177/002070201006500421

Critchley, W.H. 1984. Polar deployment of Soviet submarines. International Journal 39(4):828-865. http://dx.doi.org/10.2307/40202298

EKOS Research Associates, Inc. 2011. Rethinking the top of the world: Arctic security public opinion survey. Toronto, Ontario: Walter and Duncan Gordon Foundation.

http://munkschool.utoronto.ca/wp-content/uploads/2012/07/ ArcticCouncil_GordonFoundation_2011.pdf

- 2015. Rethinking the top of the world: Arctic public opinion survey, Vol. 2, rev. ed. Toronto, Ontario: Walter and Duncan Gordon Foundation.

Government of Canada. 2016. Arctic Waters Pollution Prevention Act (R.S.C., 1985, C. A-12).

http://laws-lois.justice.gc.ca/eng/acts/A-12/

Grant, S. 2005. Arctic justice: On trial for murder, Pond Inlet, 1923. Montréal and Kingston: McGill-Queen's University Press.

Griffiths, F. 1979. A northern foreign policy. Wellesley Papers 7. Toronto, Ontario: Canadian Institute of International Affairs.

- 2009. Towards a Canadian Arctic strategy. Foreign Policy for Canada's Tomorrow No. 1. Toronto, Ontario: Canadian International Council.

Herle, D. 2007. Poll-driven politics - the role of public opinion in Canada. Policy Options, May 1.

Huang, L., Lasserre, F., and Alexeeva, O. 2015. Is China's interest for the Arctic driven by Arctic shipping potential? Asian Geographer 32(1):59-71.

http://dx.doi.org/10.1080/10225706.2014.928785 
Huebert, R. 1999. Canadian Arctic security issues. International Journal 54(2):203-229. http://dx.doi.org/10.2307/40203373

- 2005. The return of the "Vikings": The Canadian-Danish dispute over Hans Island - new challenges for the control of the Canadian North. In: Berkes, F., Huebert, R., Fast, H., Manseau, M., and Diduck, A., eds. Breaking ice: Renewable resource and ocean management in the Canadian North. Calgary, Alberta: University of Calgary Press: 319-336.

- 2009. Canada and the changing international Arctic: At the crossroads of cooperation and conflict. In: Abele, F., Courchene, T.J., Seidle, F.L., and St-Hilaire, F., eds. Northern exposure: Peoples, powers and prospects for Canada's North. Montréal: Institute for Research on Public Policy. 28 p.

Ipsos Reid. 2006. Majority (54\%) feel P.M. was wrong not to attend recent International AIDS Conference. September 4.

http://www.ipsos-na.com/news-polls/pressrelease. aspx?id=3176

- 2008. Canada and the Arctic: True North strong and ours? August 18.

http://ipsos-na.com/news-polls/pressrelease.aspx?id=4039

- 2009. Canada's North poll: One in three (31\%) Canadians score a 'D' (18\%) or fail (13\%) a simple true or false quiz about Canada's Arctic. November 25.

http://ipsos-na.com/news-polls/pressrelease. aspx?id=4608

Lackenbauer, P.W. 2009. From polar race to polar saga: An integrated strategy for Canada and the circumpolar world. Foreign Policy for Canada's Tomorrow No. 3. Toronto, Ontario: Canadian International Council.

.2010. Mirror images? Canada, Russia, and the circumpolar world. International Journal 65(4):879-897.

Lackenbauer, P.W., and Farish, M. 2007. The Cold War on Canadian soil: Militarizing a northern environment. Environmental History 12(4):920-950.

http://dx.doi.org/10.1093/envhis/12.4.920

Landriault, M. 2013. La sécurité arctique 2000-2010: une décennie turbulente? $\mathrm{PhD}$ thesis, École d'études politiques, University of Ottawa. http://hdl.handle.net/10393/24353

Lasserre, F. 1998. Le Canada d'un mythe à l'autre: Territoires et images du territoire. Lyon: $\mathrm{HMH} /$ Presses universitaires de Lyon.

Manicom, J., and Lackenbauer, P.W. 2013. The Chinese pole. Policy Options, May 1.

http://policyoptions.irpp.org/issues/arctic-visions/manicomlackenbauer/

Nanos Research. 2008. CPAC National issue of concern. October 10 .

http://nanosresearch.com/sites/default/files/POLNATF08-T338.pdf

2009. National issues of concern. March 28.

http://www.nanosresearch.com/sites/default/files/POLNATW09-T364.pdf

_. 2010a. Healthcare remains top issue. June 17. http://nanosresearch.com/sites/default/files/POLNAT-W10T427E.pdf 2010b. Defense policy and the future of Canada's Armed Forces. October 25.

http://www.nanosresearch.com/library/polls/POLNAT-W10T443E.pdf

. 2011. Crime, jobs, food top defence spending and Arctic sovereignty. June 29.

http://nanosresearch.com/sites/default/files/POLNAT-S11T485E.pdf

- 2012. Economy up, crime down as priorities. May 24. http://www.nanosresearch.com/sites/default/files/POLNATW12-T538E.pdf

. 2014. National issue of concern - Six month comparison. October 16 .

http://www.nanosresearch.com/sites/default/files/POLNATS14-T622.pdf

Nicol, H., and Heininen, L. 2009. Networking the North: Cross border connections and the new international circumpolar geopolitics. Southern Journal of Canadian Studies 2(1):11-26.

Nossal, K.R. 2013. The Liberal past in the Conservative present: Internationalism in the Harper era. In: Smith, H.A., and Turenne Sjolander, C., eds. Canada in the world: Internationalism in Canadian foreign policy. Toronto: Oxford University Press: 21-35.

Paris, R. 2014. Are Canadians still liberal internationalists? Foreign policy and public opinion in the Harper era. International Journal 69(3):274-307. http://dx.doi.org/10.1177/0020702014540282

Pharand, D. 1979. The Northwest Passage in international law. Canadian Yearbook of International Law 17:99-133.

Public Works and Government Services Canada. 2010. Public opinion research in the Government of Canada: Annual Report 2008-2009.

http://publications.gc.ca/collections/collection_2010/tpsgcpwgsc/P100-1-2009-eng.pdf

Riddell-Dixon, E. 2008. Canada and Arctic politics: The continental shelf extension. Ocean Development \& International Law 39(4):343-359.

http://dx.doi.org/10.1080/00908320802459052

Rothwell, D. 1993. The Canadian-U.S. Northwest Passage dispute: A reassessment. Cornell International Law Journal 26(2):331372.

http://scholarship.law.cornell.edu/cilj/vol26/iss2/2

Roussel, S. 2010. La protection de l'Arctique - Les Canadiens et les Québécois, meme combat. In: Bernier, R., ed. L'espace canadien: Mythes et réalités, une perspective québecoise. Québec: Presses de L'Université du Québec. 429-445.

Roussel, S., and Fossum, J.E. 2010. The Arctic is hot again in America and Europe: Introduction to Part I. International Journal 65(4):799-808. http://dx.doi.org/10.1177/002070201006500411

Scrivener, D. 1999. Arctic environmental cooperation in transition. Polar Record 35(192):51-58.

Soroka, S.N., and Wlezien, C. 2004. Opinion representation and policy feedback: Canada in comparative perspective. Canadian Journal of Political Science 37(3):531-559. 
Stevenson, C. 2007. Hans off!: The struggle for Hans Island and the potential ramifications for international border dispute resolution. Boston College International and Comparative Law Review 30(1):263-275.

http://lawdigitalcommons.bc.edu/iclr/vol39/iss1/16

Vanderzwaag, D., and Pharand, D. 1983. Inuit and the ice: Implications for Canadian Arctic waters. Canadian Yearbook of International Law 21:53-84.
Williams, L. 2011. Canada, the Arctic, and the post-national identity in the circumpolar world. Northern Review 33:113131.

Wright, D.C. 2011. The panda bear readies to meet the polar bear: China and Canada's Arctic sovereignty challenge. Calgary, Alberta: Canadian Defense \& Foreign Affairs Institute. 